\title{
Crude Oil Contaminant and Bio-remediation using Brewery Mash and Earthworm (Nsukkadrilus mbae.) a Consortium to Cleaning-up and Restoring Soil Fertility Potentials
}

\section{Okpashi VE ${ }^{1 *}$, Igori Wallace ${ }^{2}$ and Akpo DM}

${ }^{1}$ Department of Biochemistry, University of Nigeria, Nsukka, Nigeria

${ }^{2}$ Department of Chemistry, College of Education, Oju, Benue State, Nigeria

${ }^{3}$ Department of Environmental Education, University of Calabar, Nigeria

\begin{abstract}
In this research, we perceived that some approaches adopted by environmentalist and researchers to remediate crude oil contaminated soil, by using microorganisms such as Pseudomonas aeruginosa, Aspergilus nigar and Azotobacter have obvious drawback. Thus we set out to adopt synergistic application of earthworms and brewery mash as consortiums for cleaning-up crude oil contaminated soil. The result gave significant reduction of contaminants in the soil. The efficiency of this approach arose due to considerable biological influence of earthworms in the soil by burrowing, feeding on the brewery mash, promoting aeration and facilitating rapid oxidation of the contaminants. The brewery mash was introduced as nutritional additive that would supplement for the depleted nitrogen and phosphorus, to facilitate associated feeding regimes. Wherein the brewery mash serve as carbon source to the earthworms. The results suggest that the co-application of Nsukkadrilus mbae and brewery mash promoted the reduction of both recalcitrant TPH and PAHs crude oil-contaminated soil. It equally showed that by increasing the number of earthworms, will further enhanced loss of contaminants. Considering the relative availability and affordability of earthworms and brewery mash, this approach is unarguably economical. Field application of earthworms and brewery mash for bioremediation would require careful consideration in matching earthworm treatment approach with appropriate earthworm species. Thus, earthworms enhance oil degradation via oxidation processes due to the aeration resulting from burrowing activities, increased microbial availability of hydrocarbons due to bioturbation and facilitate microbial activities. The observed increase in respiration rate by microorganisms indicates that earthworms and brewery mash have positive influence on microbial activities. In general, if given longer time, the synergistic application/activities of earthworm and brewery mash contaminants clean-up would be absolute, beneficial and economic approach to bio-remediate dissolvable and recalcitrant contaminated hydrocarbons in polluted soil.
\end{abstract}

Keywords: Earthworms; Brewery mash; Crude oil; Contaminated soil and remediation

\section{Introduction}

The activities of man associated with exploration, refining, transportation of crude oil and by-products usually results to environmental pollution. Particularly soil contamination, which poses severe threat to ground water [1]. Some constituents of crude oil are carcinogenic and potential immunotoxics [2]. The impact of crude oil spillage or discharge into the ecosystem breeds environmental concern [3], especially with associated heavy metals present in the crude oil. For instance, in Nigeria, with emphasis on the Niger Delta area, the discharge of crude oil into the environment foster consequent pollution hazard [4]. The prospecting companies and government through different agencies have at one time or the other applied divers physical, chemical or biological approaches to cleaning-up these pollutants. In soil, petroleum hydrocarbons create conditions which lead to unavailability of some essential plants nutrients such as nitrogen, phosphorus and the availability of toxic elements such as arsenic (As), lead $(\mathrm{Pb})$ and iron $(\mathrm{Fe})$ [5]. The crude oil polluted soil may remain unsuitable for crop growth over a period of time [6], until the remediation is absolute. The response of crops to oil contamination depends on the impact of contamination and degree of spillage. Light (slight) contamination may lead to weathering of crop leaves while heavy contamination results to total shading of plants leaves. The consequence of both conditions that total crop failure occurs [7]. Some organisms are known to influence the activities of ubiquitous bacteria, which rapidly respond in the presence of petroleum polluted site, have the capacity to degrade a wide range of crude oil components.
One of such organisms is earthworm. Earthworm through its enzyme and biological activities increase the soil microbial activity [8]. The numerous remediation technologies involving contaminant treatment span a wider spectrum and the choice of technology is site-specific and host dependent factors including contaminants-types. Concentration, overall treatment cost, time taken to completely clean-up minimum contaminants, concentration availablity, long-term effectiveness, future land use, and regulatory requirements [9-12]. The search for the best combination of micro and macro-organisms and nutrients for efficient bioremediation will both be time friendly, cost-effective and environmentally friendly are on top gear. There are many sources where the environment is anthropogenically consciously and unconsciously battered with pollution from crude oil and its refined product. Petroleum contamination of soils and aquifers is a real and potential environmental, health and economic problems. In general, the major concerns are the effects on economic plants, animals and human health,

${ }^{*}$ Corresponding author: Okpashi VE, Department of Business and Economic Studies, University of Naples "Parthenope", Nigeria, Tel: +234 806360 7; E-mail: vic2reshu@gmail.com

Received February 12, 2015; Accepted April 22, 2015; Published April 29, 2015

Citation: Okpashi VE, Wallace I, Akpo DM (2015) Crude Oil Contaminant and Bio-remediation using Brewery Mash and Earthworm (Nsukkadrilus mbae.) a Consortium to Cleaning-up and Restoring Soil Fertility Potentials. J Pet Environ Biotechnol 6: 223. doi:10.4172/2157-7463.1000223

Copyright: (c) 2015 Okpashi VE, et al. This is an open-access article distributed under the terms of the Creative Commons Attribution License, which permits unrestricted use, distribution, and reproduction in any medium, provided the original author and source are credited. 
Citation: Okpashi VE, Wallace I, Akpo DM (2015) Crude Oil Contaminant and Bio-remediation using Brewery Mash and Earthworm (Nsukkadrilus mbae.) a Consortium to Cleaning-up and Restoring Soil Fertility Potentials. J Pet Environ Biotechnol 6: 223. doi:10.4172/2157-7463.1000223

water table and farmlands [13]. The effects of crude oil contaminants on marine plants such as mangroves, sea-grasses, salt-mash grasses and algae has been studied, experimental ecosystems, field experiments and surveys [14,15]. Also death, reduced growth and impaired reproduction in large plants was noticed. The technologies available for the treatment of oil contaminated media vary widely from containment to removal or destruction of contaminants through burning, physical, chemical and biological treatment [16-21]. Earthworm incubation within soil promotes increased availability of nutrients and is known to increase, enhance transport and disperse metabolically active soil microbes [2225], improve soil structure and fertility via bioturbation and mixing $[22,23]$. The results of these biological, chemical and physical actions of earthworm is that it presents a number of favourable conditions for subsequent microorganism actions upon contaminants, including alteration of the availability of compounds by aiding degradation further [24]. Earthworms enhance oil degradation through enhanced oxidation processes due to the aeration resulting from burrowing activities; increased microbial availability of hydrocarbons due to bioturbation and enhanced microbial activity [25]. A number of encouraging studies have, highlighted the potential of earthworms uses to promoting hydrocarbons contaminants from soil [26-31]. Researchers have equally indicated a variance between studies and results which are suggestive to both species and compound specificity [31]. It has equally been hypothesized that the application of additional organic nutrients would greatly optimize the living conditions of earthworms by increasing food supply to promoting microbial activity [25] both effects facilitate reduction in total petroleum hydrocarbon (TPH). The choice of organic additive is cost effective dependent, availability and short transport distances. Brewery mash, also known as spent grains, is a by-product of beer brewing. It is readily available in large quantity and is produced yearly in Nigeria and the world. Brewery mash (mash) is used as forage in animal husbandry because of protein [25]. It rich in microorganisms such as yeasts, bacteria (pseudomonas) [25]. Gevao [26] suggested that the enrichment of microorganism in mash might lead to significant decrease in oil components. Hence, the nitrogen rich mash provides nitrogen and phosphorus, which the oil-degrading bacteria need to synthesize amino acids, purine and pyrimidine. The ratio at which organic additives is amended with the contaminated soil becomes very important to fasten the rate of hydrocarbon elimination from contaminated soil. For instance, at high ratio, mash to soil (1:10), microorganisms will duel much on the additive as the main source of carbon instead of breaking down the hydrocarbons. But with low mash to soil ratio (1:20), the rate of hydrocarbon degradation will increased. Thus, this research aimed at evaluating the combined effect of earthworm and brewery mash in bioremediation of crude oil- polluted soil via varying the numbers of earthworms with respect to numbers of days.

\section{Methodology}

\section{Chemicals/reagent}

All chemicals and reagents were of analytical grade, and products of Merk, Germany. British Drug House (BDH) Chemicals Ltd, Poole, England, May and Baker Ltd, England and Reidel-De-Haen Ag SeilzeHannovre, Germany.

\section{Collection of soil sample}

The test/substrate used in the research was crude oil-polluted soil. The top soil $(0-15 \mathrm{~cm})$ of crude oil-polluted soil was collected from Shell Petroleum Development Company (SPDC) Nigeria Limited flowstation, Uzere in Isoko South Local Government Area, Delta State,
Nigeria. The spill was due to the overflow that occur in August, 2008. Prior to this research, the clean-up process at the site was mopping up of the crude oil that saturated the soil, booming of the site by natural degradation and attenuation.

\section{Collection of earthworms}

Earthworms (Nsukkadrilus mbae) were collected from Boki Local Government Area, Cross River State, Nigeria. The earthworms were identified and classified by Prof. J. E. Eyo of the Department of Zoology, University, Nigeria. The earthworms weigh 0.50-0.90 g. They were acclimatized for 24 hours prior to the experiment.

\section{Brewery mash}

The nutritional additive used for the research was brewery mash (spent grains). The spent grain was collected from the Waste Management Unit, Life Breweries Nigeria limited, Onitsha, Anambra State, Nigeria. The mash was wet and air-dried at room temperature. The dried sample was sieve and the powdered was applied.

\section{Experimental design}

A total of 24 transparent cylindrical containers, measuring 14 $\mathrm{cm}$ in diameter and $15 \mathrm{~cm}$ height, were used for the experiment. The containers were perforated at the base and plugged with cotton wool to ease and create even aeration. Crude-oil polluted soil sample ( $1 \mathrm{~kg})$ was empty into each of the containers. The experiment was divided into four study groups as shown below:

Group I: Contaminated soil (Control(C))

Group II: Contaminated soil + earthworms $(\mathrm{C}+\mathrm{E})$

Group III: Contaminated soil with mash $(\mathrm{C}+\mathrm{A})$

Group IV: Contaminated soil, incubated with earthworms and $\operatorname{mash}(\mathrm{C}+\mathrm{A}+\mathrm{E})$

The groups II and III had subsets A, B and C with 5, 10 and 20 earthworms respectively. The mash was mechanically mixed and added to the contaminated soil in the ratio 1:20 (mash: soil). All the groups were made in triplicate. After incubation of the soil with earthworms, the containers were covered with net. Water was introduced periodically at week interval to aid soil humidity and regulate water holding capacity (WHC) of $62-68 \%$ at $14-20^{\circ} \mathrm{C}$. Analyses were performed on 0,14 and 28 days of the experiment.

\section{Statistical analysis}

Test of statistical significance was carried out using one-way analysis of variance together with postHoc test (multiple test comparison). Statistical difference was acceptable at $\mathrm{p}<0.05$. The Statistical Package for Social Sciences (SPSS) version 17.

\section{Results}

\section{Chemical properties of the polluted soil}

The chemical properties of the crude oil-contaminated soil used for this experiment was analyzed to ascertain its characteristics. The results showed increase concentrations of TPH and PAHs. Indicating the presence of recalcitrant crude oil contaminants in the polluted soil (Table 1).

\section{Total petroleum hydrocarbon concentration}

The result obtained from TPH analysis showed significant 
Citation: Okpashi VE, Wallace I, Akpo DM (2015) Crude Oil Contaminant and Bio-remediation using Brewery Mash and Earthworm (Nsukkadrilus mbae.) a Consortium to Cleaning-up and Restoring Soil Fertility Potentials. J Pet Environ Biotechnol 6: 223. doi:10.4172/2157-7463.1000223

Page 3 of 9

decrease $(\mathrm{p}<0.05)$ in the TPH concentration in all the treated soil samples compared to control group. Table 2 shows how the number of earthworms in the contaminated soil sample affected the concentration of total petroleum hydrocarbon (TPH), indicating significant decrease $(\mathrm{p}<0.05)$. Wherein, as the number of earthworms increase, there was observable reduction in contaminants compared to control group. Where the significant result was observable at day 28 , followed by day 14. Also, C+E20 (mg/kg) i.e 20 earthworms showed greater efficacy due to the high numbers of earthworms and closely followed by $\mathrm{C}+$ E10 (mg/kg) with 10 earthworms in day 28 and 14 respectively. Table

\begin{tabular}{|c|c|}
\hline Parameter & Value \\
\hline pH (water) & $6.2 \pm 0.20$ \\
\hline $\mathrm{pH}(\mathrm{KCl})$ & $5.40 \pm 0.15$ \\
\hline Percent carbon (\%) & $7.43 \pm 0.07$ \\
\hline Total nitrogen (\%) & $0.07 \pm 0.05$ \\
\hline Total $\mathrm{C} / \mathrm{N}$ ratio & $106: 01: 00$ \\
\hline Total nitrate (\%) & $4.6 \pm 0.05$ \\
\hline $\mathrm{Ca}^{2+}(\mathrm{Meq} . / 100 \mathrm{~g})$ & $2.0 \pm 0.08$ \\
\hline $\mathrm{Mg}^{2+}(\mathrm{Meq} . / 100 \mathrm{~g})$ & $0.6 \pm 0.07$ \\
\hline $\mathrm{Na}^{+}$(Meq./100 g) & $0.32 \pm 0.06$ \\
\hline $\mathrm{K}^{+}$(Meq./100 g) & $0.13 \pm 0.05$ \\
\hline CEC (Meq./100 g) & $2.43 \pm 0.06$ \\
\hline $\mathrm{H}^{+}$(Meq./100 g) & $2.60 \pm 0.05$ \\
\hline $\mathrm{Al}^{3+}$ (Meq. $\left./ 100 \mathrm{~g}\right)$ & BDL \\
\hline Available Phosphorus (ppm) & $21.4 \pm 0.93$ \\
\hline Microbial respiration $\left(\mathrm{mgCO}_{2}\right.$ evolved) & $129.7 \pm 2.62$ \\
\hline TPH (mg/kg) & $15056.86 \pm 92.11$ \\
\hline PAHs (ppm) & $2462.88 \pm 30.61$ \\
\hline
\end{tabular}

$\mathrm{BDL}=$ below detection limit

Table 1: The chemical properties of crude oil contaminated soil.

\begin{tabular}{|l|l|l|l|l|}
\hline & \multicolumn{4}{|c|}{ Total Petroleum Hydrocarbon (TPH) Remaining } \\
\hline $\begin{array}{l}\text { Group/ } \\
\text { Treatment }\end{array}$ & $\mathbf{C}$ (mg/kg) & C + E5 (mg/kg) & $\mathbf{C}+$ E10 (mg/kg) & C+E20 (mg/kg) \\
\hline Day 0 & $15056.86 \pm 92.11$ & $15056.86 \pm 92.11$ & $15056.86 \pm 92.11$ & $15056.86 \pm 92.11$ \\
\hline Day 14 & $12275.36 \pm 28.03$ & $13167.91 \pm 108.82$ & $9237.21 \pm 65.49$ & $11031.86 \pm 31.94$ \\
\hline Day 28 & $7590.88 \pm 1050.4$ & $7241.36 \pm 86.3$ & $6554.89 \pm 61.11$ & $4162.53 . \pm 54.49$ \\
\hline
\end{tabular}

Key:

$\mathrm{C}=$ Contaminated soil (control)

$\mathrm{C}+\mathrm{E}_{5}=$ Contaminated soil incubated with 5 earthworms

$\mathrm{C}+\mathrm{E}_{10}=$ Contaminated soil incubated with 10 earthworms

$\mathrm{C}+\mathrm{E}_{20}=$ Contaminated soil incubated with 20 earthworms

Table 2: Effect of earthworms' numbers on TPH degradation in crude oil contaminated soil.
3 shows significant decrease $(\mathrm{p}<0.05)$ in TPH concentration as the number of earthworms/brewery mash mixed with the polluted soil increase compared to the brewery mash treated and control groups. The TPH percentage loss in different groups at the end were $48-58 \%$ in the control, $46-54 \%$ in the earthworms incubated group and 88 $94 \%$ in the earthworms/brewery mash-treated groups find Table 3. Also, Figures 1 and 2 illustrate the chromatograph of PAHs and total petroleum hydrocarbons on day 0 .

The chromatogram in Figure 1, illustrate the various contaminants peaks such as polycyclic aromatic hydrocarbons present in the soil at day zero.

The Figure 2 above shows the chromatogram of the control group, illustrating various peaks of contaminants such as total petroleum hydrocarbons present in the soil at day zero.

\section{Polycyclic aromatic hydrocarbon concentration (PAHs)}

The PAHs analysis indicated that as the number of earthworms increase, PAHs concentration significantly decrease $(\mathrm{p}<0.05)$ compared to control group. This is shown in Tables 4 and 5 below.

Similarly, as the number of earthworms increases, there is a significant decrease $(\mathrm{p}<0.05)$ in PAHs concentration in the earthworms/ brewery mash-treated groups compared to brewery mash and control groups. The result of PAHs in general indicated that PAHs reduction was $84-94 \%$ in the earthworms/brewery mash, $58-64 \%$ in earthworms alone, and $49-52 \%$ in the brewery mash treated groups. Figures 3 and 4 showed the chromatograph of TPHs and PAHs at day 14.

The above chromatogram in Figure 3 shows the polycyclic aromatic hydrocarbons of earthworms plus brewery mash at day 14 depicting gradual reduction in PAHs compared (Figure 1) chromatogram. This visible ones are said to be recalcitrant contaminants.

The chromatogram in Figure 4 shows the total Petroleum Hydrocarbons components of the earthworms plus brewery mash at day 14 depicting gradual reduction in TPHs compared (Figure 2) chromatogram.

\section{Microbial respiration}

The result of determination of microbial respiration (MCR) at days 14 and 28 of the experiment generally showed a significant $(p<0.05)$ increase in all the treated groups compared to control. However, the increase was greater in the groups with twenty earthworms. As the numbers of days increased from 14 to 28 days of the experiment,

\begin{tabular}{|c|c|c|c|c|c|}
\hline \multirow[b]{2}{*}{ Group/Treatments } & \multicolumn{5}{|c|}{ Total Petroleum Hydrocarbon (TPH) Remaining } \\
\hline & $C(\mathrm{mg} / \mathrm{kg})$ & $\mathrm{C}+\mathrm{A}(\mathrm{mg} / \mathrm{kg})$ & $\mathrm{C}+\mathrm{A}+\mathrm{E} 5$ (mg/kg) & $\mathrm{C}+\mathrm{A}+\mathrm{E} 10(\mathrm{mg} / \mathrm{kg})$ & $\mathrm{C}+\mathrm{A}+\mathrm{E} 20(\mathrm{mg} / \mathrm{kg})$ \\
\hline Day 0 & $15056.86 \pm 92.11$ & $15056.86 \pm 92.11$ & $15056.86 \pm 92.11$ & $15056.86 \pm 92.11$ & $15056.86 \pm 92.11$ \\
\hline Day 14 & $12275.36 \pm 128.03$ & $10801.03 \pm 11.91$ & $3647.29 \pm 57.72$ & $2693.90 \pm 51.57$ & $1671.21 \pm 80.27$ \\
\hline \multirow[t]{2}{*}{ Day 28} & $7590.88 \pm 10.54$ & $8110.86 \pm 60.05$ & $1543.58 \pm 68.88$ & $1112.38 \pm 55.08$ & $842.85 \pm 69.75$ \\
\hline & \multicolumn{5}{|c|}{ Total Petroleum Hydrocarbon (TPH) Remaining } \\
\hline Group/ Treatments & $\mathrm{C}(\mathrm{mg} / \mathrm{kg})$ & $\mathrm{C}+\mathrm{A}(\mathrm{mg} / \mathrm{kg})$ & $\mathrm{C}+\mathrm{A}+\mathrm{E} 5$ (mg/kg) & $\mathrm{C}+\mathrm{A}+\mathrm{E} 10(\mathrm{mg} / \mathrm{kg})$ & $\mathrm{C}+\mathrm{A}+\mathrm{E} 20(\mathrm{mg} / \mathrm{kg})$ \\
\hline Day 0 & $15056.86 \pm 92.11$ & $15056.86 \pm 92.11$ & $15056.86 \pm 92.11$ & $15056.86 \pm 92.11$ & $15056.86 \pm 92.11$ \\
\hline Day 14 & $12275.36 \pm 128.03$ & $10801.03 \pm 11.91$ & $3647.29 \pm 57.72$ & $2693.90 \pm 51.57$ & $1671.21 \pm 80.27$ \\
\hline Day 28 & $7590.88 \pm 10.54$ & $8110.86 \pm 60.05$ & $1543.58 \pm 68.88$ & $1112.38 \pm 55.08$ & $842.85 \pm 69.75$ \\
\hline
\end{tabular}

Key:

$\mathrm{C}=$ Contaminated soil (control)

$\mathrm{C}+\mathrm{A} \quad=$ Contaminated soil + brewery mash

$\mathrm{C}+\mathrm{A}+\mathrm{E}_{5}=$ Contaminated soil + brewery mash +5 earthworms

$\mathrm{C}+\mathrm{A}+\mathrm{E}_{10}=$ Contaminated soil + brewery mash +10 earthworms

Table 3: Effect of earthworms' numbers amended with brewery mash on TPH degradation in crude oil contaminated soil. 


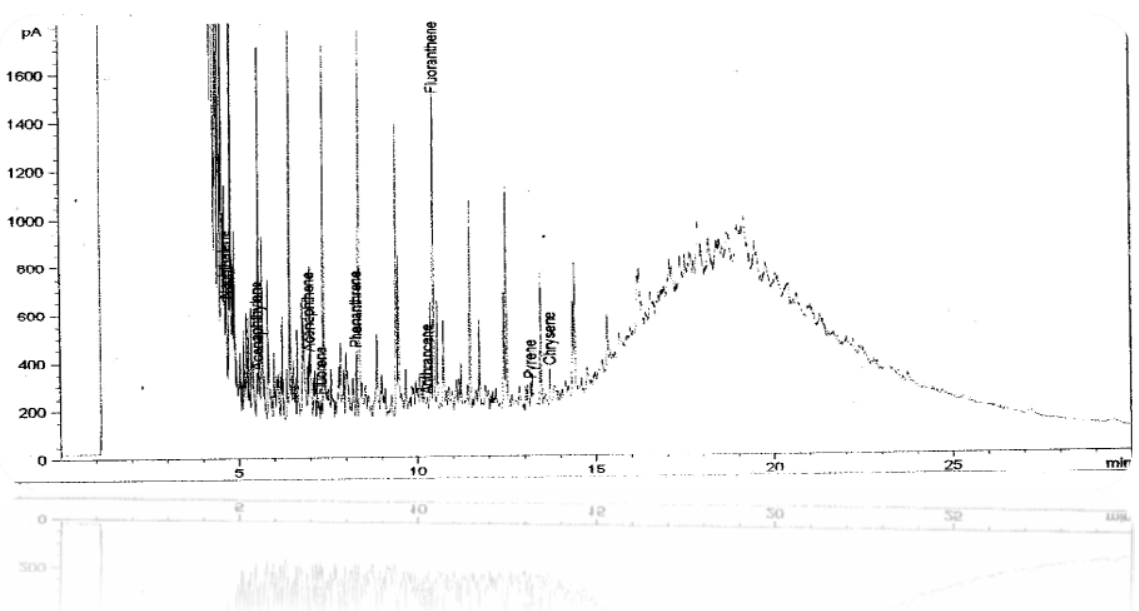

Figure 1: The PAHs chromatogram of control $(C)$ in day 0 .

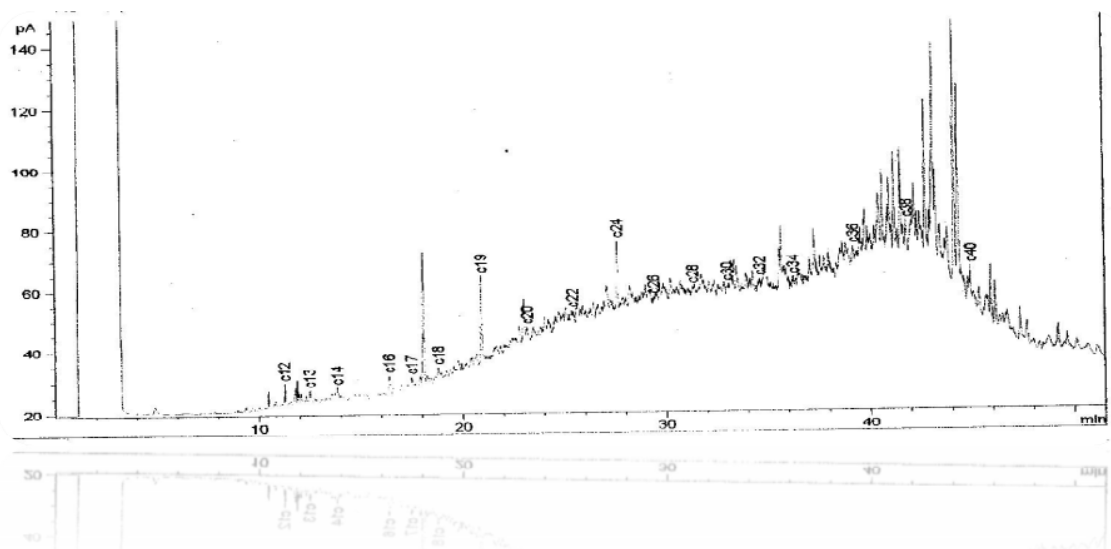

Figure 2: The TPH chromatogram of control (C) of the day 0.

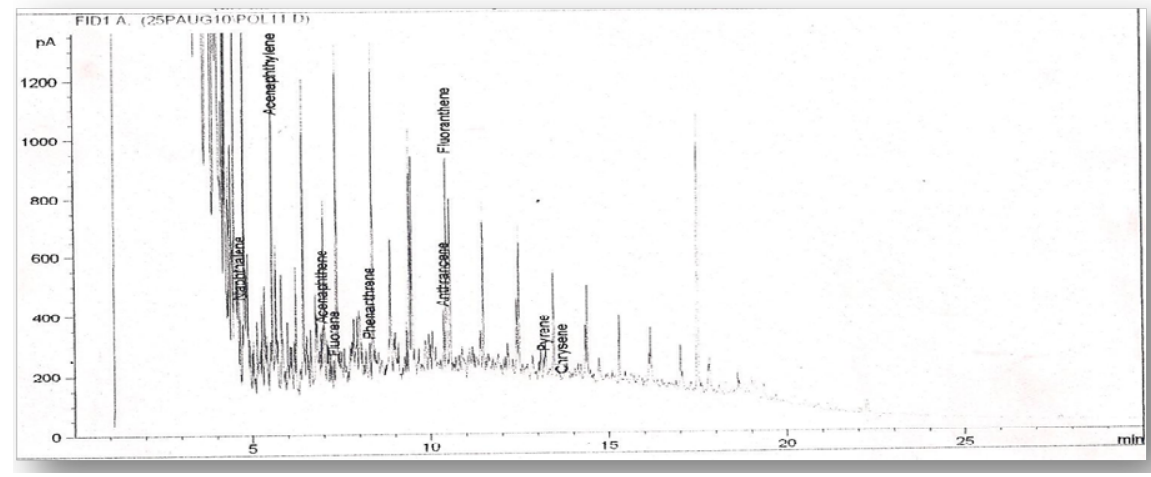

Figure 3: The PAHs chromatogram of earthworm/brewery mash $(C+A+E 20)$ in day 14.

Increase in respiration is a good indication of microbial activity which included biodegradation in the soil and the mash. It can be seen that the respiration was highest in the mash/earthworm treated soil having the highest number of earthworms. The implications of this were removal of soluble and recalcitrant contaminants.

\section{Percent organic carbon}

Table 6 shows the changes that took place at different time with respect to percent in all the groups. The results was significantly different $(p<0.05)$ from each other. Taking a close view at day 0,14 and 28 respectively. 


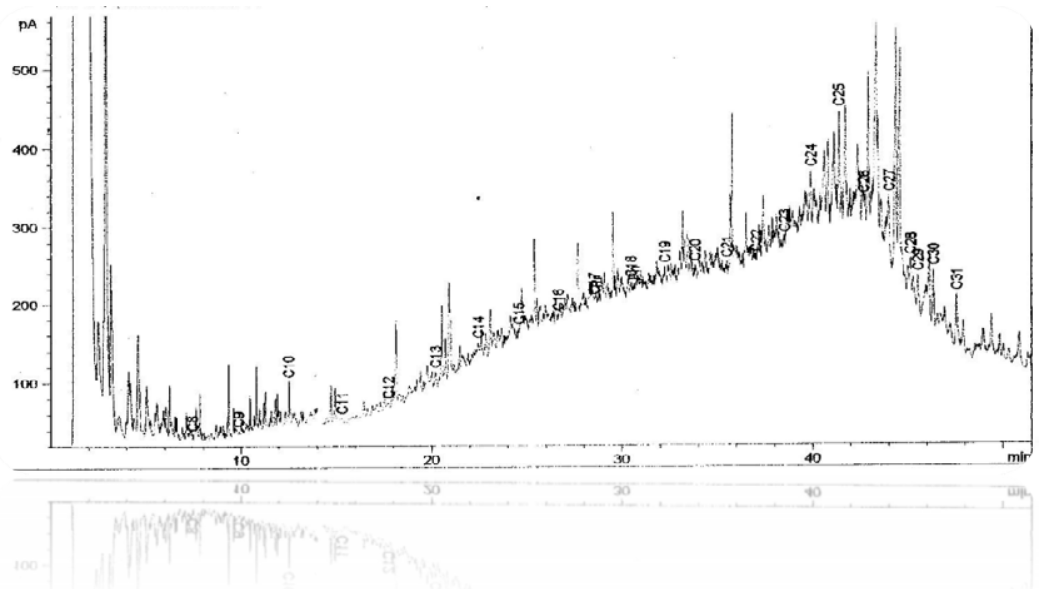

Figure 4: The Total Petroleum Hydrocarbons chromatogram of earthworm/brewery mash in day 14.

\begin{tabular}{|l|l|l|l|l|}
\hline \multicolumn{4}{|c|}{ Polycyclic Aromatic Hydrocarbon (PAH) Remaining } \\
\hline Group/Treatment & C $(\mathbf{p p m})$ & C + E5 $(\mathbf{p p m})$ & \multicolumn{1}{|c|}{ C+E10 (ppm) } \\
\hline Day 0 & $2462.88 \pm 30.61$ & $2462.88 \pm 30.61$ & $2462.88 \pm 30.61$ \\
\hline Day 14 & $2339.86 \pm 31.95$ & $1241.88 \pm 22.30$ & $1370.98 \pm 24.06$ \\
\hline Day 28 & $2106.56 \pm 31.04$ & $1077.60 \pm 21.22$ & $1160.78 \pm 25.87$ & $1076.40 \pm 23.42$ \\
\hline
\end{tabular}

Key:

$\mathrm{C}=$ Contaminated soil (control)

$\mathrm{C}+\mathrm{E}_{5}=$ Contaminated soil incubated with 5 earthworms

$\mathrm{C}+\mathrm{E}_{10}=$ Contaminated soil incubated with 10 earthworms

$\mathrm{C}+\mathrm{E}_{20}=$ Contaminated soil incubated with 20 earthworms

Table 4: Effect of earthworm's numbers on PAHs degradation in crude oil contaminated soil.

\begin{tabular}{|l|l|l|l|l|l|}
\hline \multicolumn{4}{|c|}{ Polycyclic Aromatic Hydrocarbon (PAH) Remaining } \\
\hline Group/Treatment & C $(\mathbf{p p m})$ & C+A (ppm) & C+A+E5 (ppm) & C+A+E10 (ppm) & C+A+E20 (ppm) \\
\hline Day 0 & $2462.88 \pm 30.61$ & $2462.88 \pm 30.61$ & $2462.88 \pm 30.61$ & $2462.88 \pm 30.61$ \\
\hline Day 14 & $2339.86 \pm 312.96$ & $1398.48 \pm 30.38$ & $636.25 \pm 25.92$ & $397.28 \pm 27.52$ \\
\hline Day 28 & $2106.56 \pm 308.04$ & $1275.99 \pm 21.82$ & $375.12 \pm 25.87$ & $142.37 \pm 22.95$ & $137.92 \pm 26.73$ \\
\hline
\end{tabular}

Key:

$\mathrm{C}=$ Contaminated soil (control)

$\mathrm{C}+\mathrm{A} \quad=$ Contaminated soil + brewery mash

$\mathrm{C}+\mathrm{A}+\mathrm{E}_{5}=$ Contaminated soil + brewery mash +5 earthworms

$\mathrm{C}+\mathrm{A}+\mathrm{E}_{10}=$ Contaminated soil+ brewery mash +10 earthworms

$\mathrm{C}+\mathrm{A}+\mathrm{E}_{20}=$ Contaminated soil + brewery mash +20 earthworm

Table 5: Effect of earthworm's numbers on PAHs degradation in crude oil contaminated soil amended with brewery mash.

\begin{tabular}{|c|c|c|c|}
\hline \multicolumn{4}{|c|}{ Percent Organic Carbon Remaining } \\
\hline Group/Treatment (\%) & Day 0 & Day 14 & Day 28 \\
\hline Control (C) & $7.42 \pm 0.07$ & $7.01 \pm 0.24$ & $7.14 \pm 0.06$ \\
\hline C + E5 & $7.42 \pm 0.07$ & $4.01 \pm 0.08$ & $3.65 \pm 0.25$ \\
\hline C + E10 & $7.42 \pm 0.07$ & $3.86 \pm 0.15$ & $3.59 \pm 0.07$ \\
\hline C + E20 & $7.42 \pm 0.07$ & $3.71 \pm 0.08$ & $3.32 \pm 0.07$ \\
\hline C + A & $7.42 \pm 0.07$ & $3.75 \pm 0.09$ & $3.65 \pm 0.06$ \\
\hline C + A + E5 & $7.42 \pm 0.07$ & $3.37 \pm 0.07$ & $3.24 \pm 0.07$ \\
\hline C + A + E10 & $7.42 \pm 0.07$ & $3.62 \pm 0.08$ & $3.24 \pm 0.05$ \\
\hline C + A + E20 & $7.42 \pm 0.07$ & $3.48 \pm 0.06$ & $3.16 \pm 0.07$ \\
\hline
\end{tabular}

Values are mean $\pm S D(n=3)$

Key:

$\mathrm{C}=$ Contaminated soil (control)

$\mathrm{C}+\mathrm{E} 5=$ Contaminated soil incubated with 5 earthworms

$\mathrm{C}+\mathrm{E} 10=$ Contaminated soil incubated with 10 earthworms

$C+E 20=$ Contaminated soil incubated with 20 earthworms

$C+A=$ Contaminated soil + brewery mash

$C+A+E 5=$ Contaminated soil + brewery mash +5 earthworms

$\mathrm{C}+\mathrm{A}+\mathrm{E} 10=$ Contaminated soil + brewery mash +10 earthworms

$\mathrm{C}+\mathrm{A}+\mathrm{E} 20=$ Contaminated soil + brewery mash +20 earthworms

Table 6: Changes in soil percent organic carbon at days 0, 14 and 28.

\section{Discussion}

Earthworm in soil promotes increased availability of nutrients and is known to increase, enhance, transport and disperse metabolicallyactive soil microbes [22,23]. Thus, earthworms enhance oil degradation via oxidation processes due to the aeration resulting from burrowing activities; increased microbial availability of hydrocarbons due to bioturbation and microbial activity [25]. Similarly, brewery mash (spent grain) is rich in microorganisms and equally has high contents of yeast which oxidize total petroleum hydrocarbons with oxygen, and use the oxidized products in their metabolism as carbon source [25]. Table 1 shows the chemical characteristics of crude oil contaminants, with element such as $\mathrm{Al}^{3+}$ (Meq./100g) were below detection limit. the $\mathrm{pH}$ (water) $\left.6.2 \pm 0.20, \mathrm{pH}(\mathrm{Kcl}) 5.40 \pm 0.15, \mathrm{Mg}^{2+} \mathrm{Meq} . / 100 \mathrm{~g}\right), 0.6 \pm$ 0.07 and total nitrate (\%) $4.6 \pm 0.05$ respectively. Whereas, Available Phosphorus $(\mathrm{ppm}) 21.4 \pm 0.93$, microbial respiration $\left(\mathrm{mg} / \mathrm{CO}_{2}\right.$ evolved) $129.7 \pm 2.62$, total petroleum hydrocarbons (TPHs) $(\mathrm{mg} / \mathrm{kg}$ ) $15056.86 \pm 92.11$ and polycyclic aromatic hydrocarbons (PAHs) (ppm) $2462.88 \pm 30.61$. Hence, the nitrogen rich brewery mash provides a 


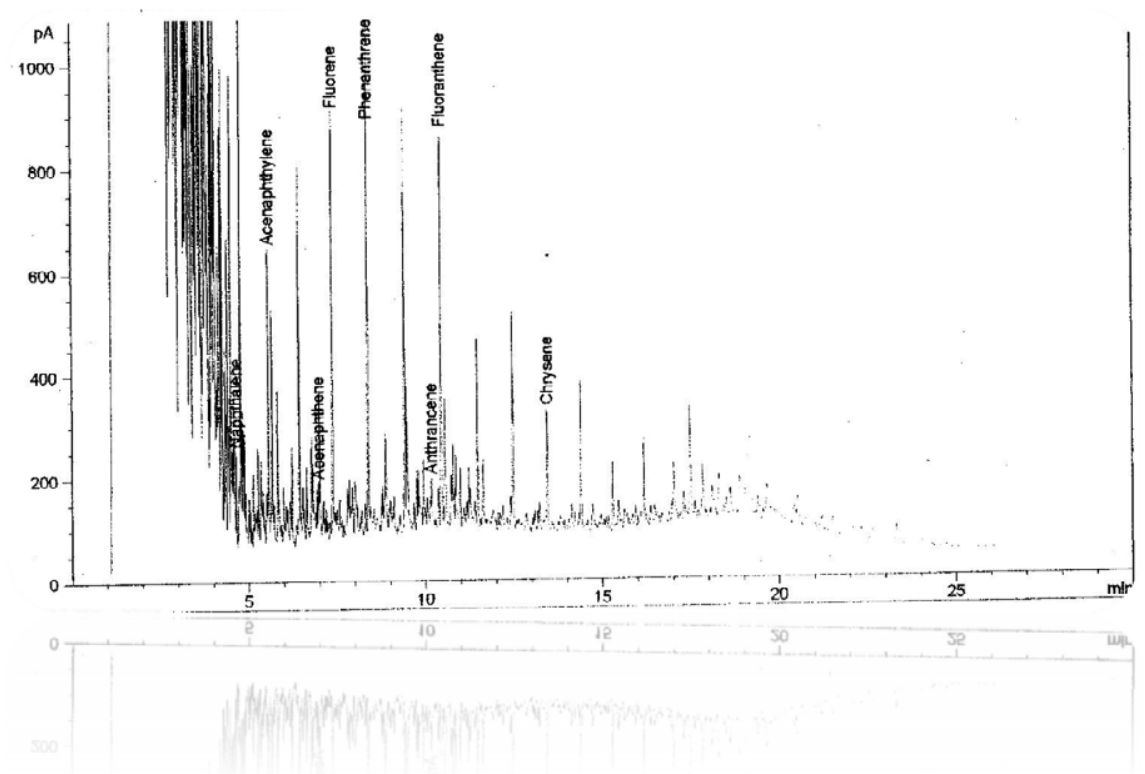

Figure 5: The PAHs chromatogram of earthworm/brewery mash $(C+A+E 20)$ in day 28.

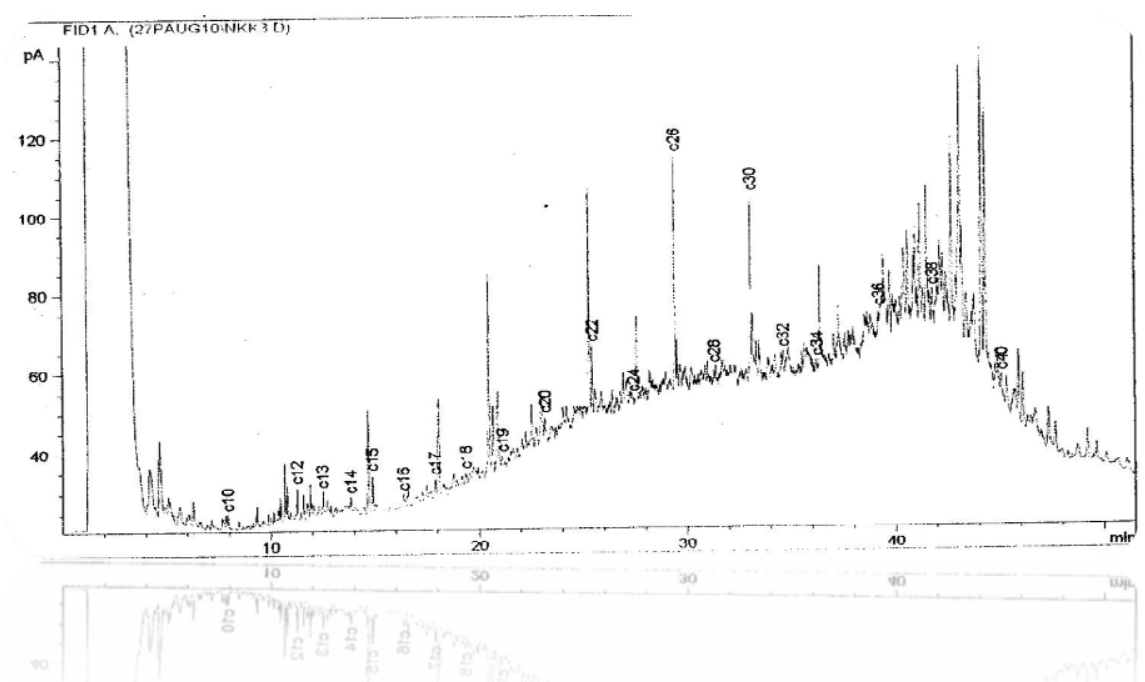

Figure 6: The TPH chromatogram of the control of the day 28.

nitrogen and phosphorus source, which the oil-degrading bacteria need to synthesize amino acids, purine and pyrimidine [32]. Thus this study revealed the synergistic potential of earthworms (Nsukkadrilus mbae) and brewery mash to enhance biodegradation of residual petroleum hydrocarbons in oil-contaminated soil, and to restoring soil fertility. The significant decrease in hydrocarbons (TPH and PAH) $(\mathrm{p}<0.05)$ and percent organic carbon $(\% \mathrm{OC})$, the significant increase $(\mathrm{p}<0.05)$ in microbial respiration $(\mathrm{MCR})$ were potentially promoted in the earthworm treatment. Table 2 shows the Effect of number of earthworms on TPH degradation in the crude oil-contaminated soil, on day 0,14 and 28 [26,29], portray similar results which states that physical actions (aeration, input of nutritionally-rich matters, bioturbation and increased soil surface area where responsible for microbial interaction), as previously reported by $[27,29,31,33,34]$. The $88-94 \%$ TPH level of reduction in the combined earthworms and mash treatment was in good agreement with the results published by [35], but was contrary only to the mixture ratio, where he concluded that such degree of reduction is obtainable only when $50 \%$ additive (compost) is used. Table 3, explain the effect of number of earthworms amended with brewery mash on total petroleum hydrocarbons (TPHs) degradation in crude oil contaminated soil. Results indicated that $\mathrm{C}+\mathrm{A}+\mathrm{E} 20(\mathrm{mg} / \mathrm{kg})$ have the highest activities $842.85 \pm 69.750$ n day 28, compare to $\mathrm{C}+\mathrm{A}(\mathrm{mg} / \mathrm{kg})$ day $28, \mathrm{C}+\mathrm{A}+\mathrm{E} 5(\mathrm{mg} / \mathrm{kg})$ day 28 , and $\mathrm{C}+\mathrm{A}+\mathrm{E} 10(\mathrm{mg} / \mathrm{kg})$ day 28 respectively. Showing that Mash mixed into soil alone resulted in TPH (46-54\%) reduction, while $48-58 \%$ reduction in TPHs was observed in the treatments with earthworms but without 


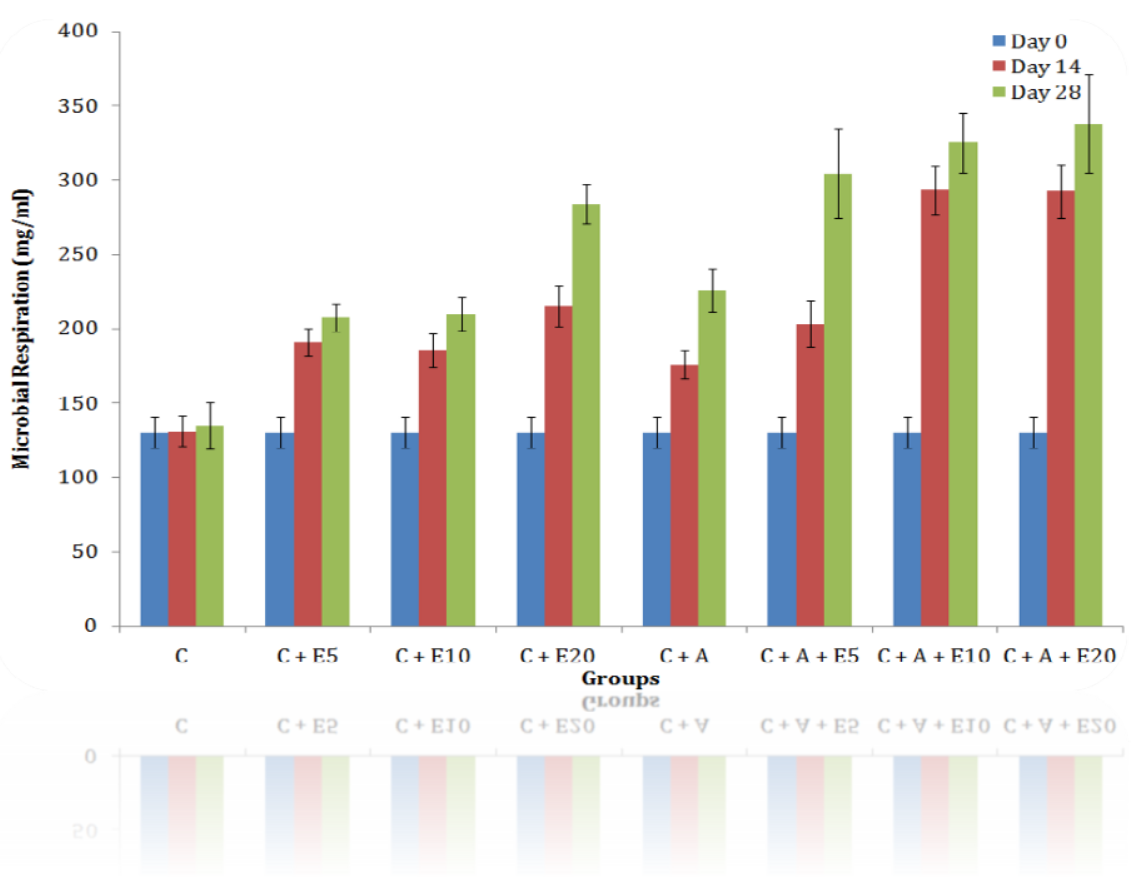

Figure 7: Changes in microbial respiration (MCR) of soils at days 0,14 and 28 at variable soil treatments.

mash. Figures 1-6 showed the chromatograms of some compounds in PAHs and TPHs detected at various peaks. This result corresponds to the observations of Schaefer [25] and Singer [35] who individually determined the loss of hydrocarbons of $20-34 \%$ and $23-31 \%$ respectively per month in comparable soils amended with fertilizers. Table 3 showed the effect of number of earthworms on PAHs degradation capacity of earthworms in the crude oil contaminated soil, which followed the same trend with Tables 4 and 5 which shows the effect of earthworm's numbers on PAHs degradation in crude oil contaminated soil amended with brewery mash. The significant reduction in PAHs $(\mathrm{p}<0.05)$ in all treatments and especially the $86-94 \%$ loss in the combined earthworms and mash-treated group corroborated the assertion that earthworms through their biological and physical activities enhanced PAHs degradation in crude oil-polluted soils as reported by Schaefer [24] and $\mathrm{Ma}$ [27]. There was a significant increase $(\mathrm{P}<0.05)$ in percent nitrogen in the earthworms and mash treatments, and a decrease in $\mathrm{C} / \mathrm{N}$ ratio (an index of increased soil fertility) if we resort to Table 1 . This increase resulted from rapid mineralization of the available nitrogen in the mash, in consonance with previous findings of Contreras [31] and Schaefer [25]. This percent nitrogen increase could also have resulted from the rich nitrogenous cast of the earthworms. Also, the overall significant increase in available phosphorus observed in the combined earthworms and mash-treated groups on day 28 of the experiment could be attributed to combined influence of phosphorus contained in both mash and earthworms casting, and were indications of soil fertility recovery, suitable for agricultural purposes. Soil microbial respiration measurement revealed a significant increase $(\mathrm{p}<0.05)$ in microbial activities in the earthworm treatments, compared to the control and thus was in good agreement with previous studies which indicated that soil incubated with earthworms and nutrients increased microbial activities [36]. Earthworms are known to increase respiration rates in various soils. See Figure 7 which shows the changes in microbial respiration (MCR) of soils at days 0,14 and 28 of different soil treatments $[28,37,38]$. Callaham found that the addition of earthworms and/or organic material increased respiration rates in oil-contaminated soil. It has also been reported that soil respiration in soil samples treated with earthworms and additives was higher than in the corresponding treatments with earthworms alone [39]. The percentage of organic carbon is shown in Table 6. Thus, there was evidence that earthworms stimulate carbon mineralization when sufficient food materials (rich in nitrogen) are present or added. Naturally-occurring microbes are responsible for the ready degradability of crude oil hydrocarbons (alkanes, alkenes, aromatics) in soil, sludge and sediments. The observed increase in soil respiration rate indicates that earthworms and brewery mash have a positive influence on microbial activities. Similarly, the sole application of brewery mash gave a TPH and PAH reductions higher than the controlled group (crude oil contaminated soil), but lower than the mash and earthworms incubated groups at the end of the investigation which, probably was due to the comparatively quick net nitrogen mineralization of mash [40]. Therefore, earthworms may be useful tools for optimizing remediation of crude oilcontaminated soil, and their efficiency increased at a moderate TPH concentration [25] also suggested that the density of earthworms used in bioremediation of crude oil-contaminated sites probably do not exceed those normally found under normal field conditions, which varies from species to species. In view of this study, there is greater evidence to the synergistic benefits of combining earthworms and brewery mash for the fertility restoration of long standing crude oilpolluted agricultural soil. Earthworm count on the last day of the experiment indicates a mortality rate $46-50 \%$ and $75-79 \%$ in the mashamended and non-amended groups respectively. This variation could be in agreement with [41] and suggest that the mash served as food source to the earthworm and/or had increased the microbial activity of the oil-contaminated soil.

Consequently, earthworm species that are easily available, cultured (vermiculture) and/or purchased in high quantity should be considered. 
Citation: Okpashi VE, Wallace I, Akpo DM (2015) Crude Oil Contaminant and Bio-remediation using Brewery Mash and Earthworm (Nsukkadrilus mbae.) a Consortium to Cleaning-up and Restoring Soil Fertility Potentials. J Pet Environ Biotechnol 6: 223. doi:10.4172/2157-7463.1000223

Page 8 of 9

\section{Conclusion}

This research conclude that, the combined use of earthworm (Nsukkadrilus mbae) and brewery mash showed alternative tool that can be applied to treating recalcitrant contaminants in the soil. It should be used as a polishing step after conventional mechanical cleanup. The results of this research study suggest that the co-application of Nsukkadrilus mbae and brewery mash promoted and enhanced both recalcitrant $\mathrm{TPH}$ and $\mathrm{PAH}$ loss in crude oil-contaminated soil. It equally showed that increasing the number of earthworms still further promoted additional loss, and considering the relative availability and affordability of earthworms and mash, this approach becomes unarguably economical. Field application of earthworms and mash for bioremediation would require careful consideration in matching earthworm treatment approach with appropriate earthworm species. Therefore, an epigeic earthworm would be best in a window treatment where little burrowing would take place, whilst an endogeic earthworm would be suited for deeper treatment systems where deeper burrowing is required. Considering the mortality of earthworms used in this study, we suggests that prior to incubation/exposure of earthworms to the polluted soil adequate and mature earthworms are required to avoid acute toxicity and shock. This will effectively promote tolerance and enhance further hydrocarbon degradation. Since earthworms have the capacity to thrive and survive in moderately crude oil contaminated soil. The efficiency of this approach would be promoted through a choice of nutritional additive that would supplement for the depletion of nitrogen and phosphorus associated with feeding regimes. Largely, the synergistic activities of earthworm and brewery mash would be beneficial in cleaning-up contaminants in the polluted soil to bioremediate recalcitrant hydrocarbon contaminated soil.

\section{References}

1. Mishra S, Jyot J, Kuhad RC, Lal B (2001) Evaluation of inoculum addition to stimulate in situ bioremediation of oily-sludge-contaminant soil. Applied and Environmental Microbiology 67: 1675-1681.

2. Propts TL, Lochmiller RI, Qualls Jr CW, McBee K (1999) In situ (mesocosm) assessment of immunotoxicity risks to small mammals inhabiting petrochemical waste sites. Chemosphere 38: 1049-1067.

3. Bollag JM, Loll MJ (1983) Incorporation of Xenobiotic into humus. Experientia 39: $1221-1231$

4. Antia SP, Mgbomo E (1993) Patterns of Degradation of Bonny light crude oil by Bacillus $s p$ and Pseudomonas $s p$ isolated from oil-spilled sites. West African Journal of Biological and Applied Chemistry 39: 1-4.

5. Roane TM, Kellogg ST (1996) Characterization of bacterial communities in heavy metal contaminated soil. Canadian Journal of Microbiology 42: 593-603.

6. Coon NC, Dieter MC (1981) Responses of adult Mallard Dusks to ingested South Louisiana crude oil. Environmental Response 24: 309-314.

7. Akamigbo FOR, Jidere CM (2002) Carbon-Nitrogen dynamics in organic wastes amended-crude oil polluted wetland soil. Agro-Science Journal of Tropical Agriculture, Food, Environment and Extension. 3: 20-26.

8. Dubey RC (2006) A textbook of biotechnology. Chand, S. (ed.). S Chand and Company, India: 569-598

9. Ram NM, Bass DH, Falotico R, Leahy M (1993) A decision framework for selecting remediation technologies at hydrocarbon-contaminated sites. Journal of Soil Contamination 2: 167-189.

10. Cutright TJ, Lee S (1994) In situ soil remediation: bacteria or fungi. Energy Sources 17: 413-419.

11. Colleran E (1997) Uses of bacteria in bio-remediation. In Sheehan, D. (ed). Methods in Biotechnology-Bioremediation Protocols. Humana Press, New Jersey: 3-21.

12. Okpokwasili GC, Oton NS (2006) Comparative applications of bioreactor and shake-flask systems in the treatment of oily-sludge. International Journal of Environment and Waste Management 1: 49-60.

13. Onwurah INE (2000) A Perspective of Industrial and Environmental Biotechnology. Snaap Press Ltd, Enugu, Nigeria: 55-105.

14. Winters J, O'Donnell R, Batterton JC, Van BC (1976) Water-components of four fuel oils: chemical characterization and effects on growth of microalgae. Marine Biology 36: 269-279.

15. Odu CTI (1981) Nitrogen Accretion in Oil Polluted Soils. In: Current Perspective in Nitrogen Fixation. Ausrtralian Academy of Science: 52-57.

16. Griffiths RA (1995) Soil-washing technology and practice. Journal of Hazardous Materials 40: 175-189.

17. Sikdar SK, Grosse D, Rogut IJ (1998) Membrane technology for remediating contaminated soil, a critical review. Journal of Membrane Science 151:75-85.

18. Amarante D (2000) Applying in situ chemical oxidation. Pollution Engineering 32: $40-42$.

19. N'Guessen AL, Alderman SC, O'Connor K, Ainiz Z, Rahim A, et al. (2001) Peroxy-acid treatment of selected PAHs in sediments. International Journal of Environment and Waste Management 1: 61-74.

20. Rogers SW, Ong SK, Kjartanson BH, Golchin J, Stenback GA (2002) Natura attenuation of polycyclic aromatic hydrocarbon- contaminated sites, review. Practice Periodical of Hazardous, Toxic and Radioactive Waste Management 6: 141-155.

21. Lo I (2003) Innovative remedial technologies for subsurface contamination. Practice Periodical of Hazardous, Toxic, and Radioactive Waste Management 7: 2-7.

22. Edwards CA, Bohlen CJ (1996) Biology and Ecology of Earthworms. $3^{\text {rd }}$ edition, Chapman and Hall, London: 6-17.

23. Edwards CA (1998) Earthworm Ecology. St Lucie Press, Boca Raton. Illinois: $14-20$

24. Schaefer M, Peterson SO, Filser J (2005) Effects of Lumbricu chlorotica Allolobophora chlorotica and eisenia fetida on microbial community dynamics in oil-contaminated soil. Soil Biology and Biochemistry 37: 2065-2076.

25. Schaefer M, Filser J (2007) The influence of earthworms on organic additives on the biodegradation of contamination soil. Applied Soil Ecology 36: 53-62.

26. Gevao B, Morduant C, Semple KT, Piearce TG, Jones KC (2001) Bioavailability of non-extractable (bound) pesticide residues to earthworms. Environmental Science and Technology 35: 501-507.

27. Ma WC, Immerzeel J, Bodt J (1995) Earthworm and food interactions on bioaccumulation and disappearance in soil of polycyclic aromatic hydrocarbons: studies on phenanthrene and fluoranthene. Ecotoxicology and Environmental Safety 32 : 226-232.

28. Meharg AA (1996) Bioavailability of atrazine to soil microbes in the presence of the earthworm lumbricus terrestrius. Soil Biology and Biochemistry. 28: 555 559.

29. Schaefer M (2001) Earthworms in crude oil contaminated soils: Toxicity Tests and Effects on Crude Oil Degradation. Soil Sediment and Water 8: 35-37

30. Binet F, Kersante A, Munier LC, La Bayon RC, Belgy MJ, et al. (2006) Lumbricid macro-fauna alter atrazine mineralization and sorption in a silt loam soil. Soil Biochemistry 38: 1255-1263.

31. Contreras Ramos SM, Alvarez Bernal D, Dendooven L (2006) Eisenia fetida increased removal of polycyclic aromatic hydrocarbons from soil. Environmental Pollution 141: 396-401.

32. Hickman ZA, Reid BJ (2008) Earthworm assisted bioremediation of organic contaminants. Environment International 34: 1072- 1081.

33. Margesin R, Zimmerbauel A, Schinner F (2000) Monitoring of bioremediation by soil biological activities. Chemosphere 40: 339-346.

34. Jidere CM, Akamigbo FOR (2009) Hydrocarbon degradation in poultry droppings and cassava peels-amended typic paleustults in southeastern Nigeria. Agro-Science Journal of Tropical Agriculture, Food, Environment and Extension 8: 24-30

35. Singer AC, Jury W, Leupromanchai E, Yahng CS, Crowley DE (2001) Contribution of earthworms to PCB bioremediation. Soil Biology and Biochemistry 33: 765- 775 . 
Citation: Okpashi VE, Wallace I, Akpo DM (2015) Crude Oil Contaminant and Bio-remediation using Brewery Mash and Earthworm (Nsukkadrilus mbae.) a Consortium to Cleaning-up and Restoring Soil Fertility Potentials. J Pet Environ Biotechnol 6: 223. doi:10.4172/2157-7463.1000223

Page 9 of 9

36. Scheu S (1987) Microbial activity and nutrient dynamics in earthworm casts (Lumbricidae). Biology and Fertility of Soils 5: 230-234

37. Namkoong W, Hwang EY, Park JS, Choi JY (2002) Bioremediation of diese contaminated soil with composting. Environmental. Pollution 119: 23-31.

38. Dorn PB, Salanitro JP (2000) Temporal ecological assessment of oilcontaminated soils before and after bioremediation. Chemosphere 40 : 419-426.
39. Atlas RM, Bartha R (1992) Hydrocarbon biodegradation and oil spill bioremediation: in Marshal, K.C. (ed). Advances in Microbial Ecology 12: 287-338.

40. Maraun M, Alphei J, Bonkoski M, Buryn R, Migge S, et al. (1999) Middens of the earthworm Lumbricus terretris are important microhabitants for micro- and meso-fauna in forest soil. Pedobiology 43: 276-287.

41. Callaham Jr MA, Stewart AJ, Alarcon C, McMilien SJ (2002) Effects of earthworms (Eisenia fetida) and wheat (Triticum aestivum) straw additions on selected properties of petroleum-contaminated soils. Environmental Toxicology and Chemistry 21: 1658-1663. 